\title{
STRESS IN THE MILITARY - A PERSPECTIVE
}

\author{
Cpl J.B. Bloom*
}

\section{INTRODUCTION}

The concepts of stress and stress management have drawn increasing attention as the issues they adress seem set to become a major part of man's response to the future shock of rapid, threatening change. As with other established institutions, the military is immune neither from the vast currents of change characteristic of the twentieth-century nor consequent pressures for adaptation.

Since World War II, the rate of technological advancement in the military sphere has been accelerated to the point where it almost staggers the imagination. The galloping obsolescence of new weapons systems has profound implications, as the ever-increasing technological sophistication of warfare. It has thus been pointed out that the battlefield of the future, with its stark possibility of continuous day-night combat with nuclear, biological and chemical weapons, could well provoke psychiatric casualties that after 30 days may begin to exceed battle casıalties. ${ }^{1}$

Less dramatic than the combat environment, but no less profound in its implications, is the rapidly changing nature of the societal environment within which the military has to function. The gulf between the military and the society it serves to protect has widened, alienating and causing problems with discipline among its more educated recruits. The key dilemma, as stated by General Kerwin, is that "the values necessary to defend (a democratic) society are often at odds with the values of the society itself ... the Army must concentrate not on the values of our liberalised society, but on the hard values of the battlefield". ${ }^{2}$ Military sociologists note the tensions created by the attempt to mix management technology with a service oriented, self-sacrificing institution whose values of duty, honour, integrity and discipline have deteriorated in the face of an anti-authoritarian, individualistic society. ${ }^{3}$

As compared to sectors of industry, the military is confronted with its own unique set of stresses. Unlike any business undertaking, it is concerned with issues of life and death. It is unsurprising, therefore, that the traditional Spartan military ethic implies demands which emphatically include the "excessive". As Zais and Taylor have pointed out, the emphasis has long been placed on mission accomplishment over individual welfare, austerity, physical and mental rigour, and the unlimited liability of the soldier, extending to the risk of life itself. ${ }^{4}$

The background, then, is of a uniquely demanding institution facing its own severe pressures for adaptation in a changing world and in turn transmitting these pressures to its hard-pressed members. Symptoms of an inability to cope with the unique stresses of this environment may be detected in terms of decreased efficiency, lower moral and increased turnover of permanent force personnel. The issue of an all-encompassing philosophy or doctrine of stress management for the military thus becomes of paramount importance.

It is towards contributing to such a philosophy that this article sets out firstly to present a brief analysis of the nature of stress, followed by the lessons to be derived from a historical examination of military responses to the stresses of combat. Also covered are appropriate theoretical conceptions relating to the case of the psychiatric casualty. Following the categorisation of Zais and Taylor, the two other general sources of stress in the military, deriving from the jobs and the enigencies of the military life-style, are then outlined. Finally some possible preventive strategies and appropriate coping responses to these three types of stresses - combat-specific, jobrelated and military life-style - are examined in detail.

\section{THE NATURE OF STRESS}

The concept of stress is an elusive one, and there is in fact no single agreed definition of existence. An inexact definition given by $\mathrm{Dr}$. Hans Selye, the founding father of stress research, is that it is simply "the rate of wear and 
tear in the body". Perhaps the most adequate approach, however, is one that views stress as the reflection of a "lack of fit" between the person and his environment. What gives rise to the experience of stress is an imbalance between the demand on the person and his ability to cope. $^{5}$

Most importantly, the human organism has a limited stress capacity. If psychological and physiological coping is ineffective, the stress is prolonged and abnormal responses may occur which could give rise to injury, illness or even death. Stress is now known to be a contributor, either directly or indirectly, to coronary heart disease, cancer, lung ailments, accidental injuries, chirrosis of the liver and suicide. ${ }^{6}$

Of further interest is the relationship of stress to job performance and productivity, which appears to be in the form of an inverted $U$ curve (see diagram below). ${ }^{7}$ When stress is low, productivity is low. As the level of stress increases, the level of productivity rises until high levels of stress cause it to drop.

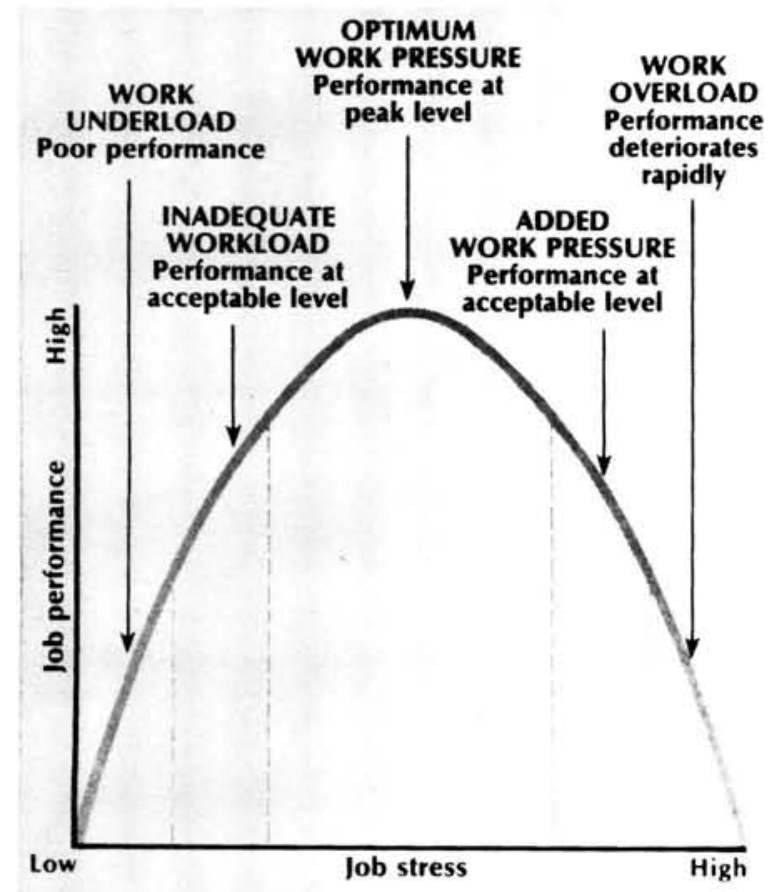

Relationship of stress to performance and pro. ductivitv.

(Army Logisticlan, July-August 1982)

Recent research measuring the body's biochemical responses to stress has led to an appreciation of individual differences and the fact that it is the perception of an event which determines whether or not it is experienced as stressful. There is now also strong evidence that social factors may exert a significant effect in altering an individual's perception of stress eg. the leadership role has been found to increase arousal as measured by adrenal-cortical secretion. Overall, Peter Bowne concludes that in the investigation of man's response to stress, attention must be paid to the threat itself, the psychological style of the individual in coping with his environment, and the social context in which he exists. $^{8}$

\section{COMBAT-RELATED STRESS REACTIONS}

\section{Historical Background}

Combat psychiatry is of relatively recent origin and grew out of the need to care for individuals who were rendered ineffective by psychological disintegration under the stresses of battle. The first acknowledgement of the existence of combat stress reactions as a clinical entity has been traced to the American Civil War, where it was refered to as "nostalgia". it was not until World War I, however, that the planning for psychological casualties became an integral part of the overall medical organization. In previous wars, such failures of adaptation were regarded as cowardice or moral weakness, to be punished as violation of military discipline. ${ }^{9}$

Glass has pointed out that failure in the combat role needs to be manifested by symptoms or behaviour which is acceptable to the morals and standards of the group as indicating an inability rather than an unwillingness to function. ${ }^{10} \mathrm{Be}$ cause of this importance of acceptability, manifestations of combat psychiatric casualties and usually their terminologies have generally indicated a direct link with various traumatic conditions of the battlefield. In short, how such casualties behave seems to depend upon both the nature of the war and how they are labelled.

\section{"Shell Shock"}

With the intensive shelling characteristic of World War I, some soldiers became dazed, tremulous, confused, or blind, deaf or paralysed with no neurological reason. The diagnosis of "shell shock" was accepted by both soldiers and medical personnel, and it was initially assured that these symptoms resulted from temporary or more persistent brain damage. It later became evident to the Allied Medical Services, however, that it was entirely a psychological disorder, a 
recognition that interestingly was never endorsed by the German High Command. ${ }^{11}$

\section{"War Neuroses"}

Between WW I and WW II, the diagnosis of psychiatric casualties became established as the "war neuroses". These came to be regarded as originating mainly from individuals who were vulnerable to battle or other situational stress by reason of predisposing character or personality defects. The reasoning was therefore that military psychiatric problems could be largely prevented by exclusion through screening examination at induction. The mass failure of this approach is evidenced by the fact that in 1943 the incidence of psychiatric disorders in the US Army was three times that of WW I, despite a psychiatric rejection rate which was three to four times greater. ${ }^{12}$ Overall, almost a million American men were rejected for military service because of emotional defects, and an almost equal number discharged prematurely because of emotional instability, ineptitude, or undesirable traits of character. ${ }^{13}$

The commonly used label "psychoneurosis" implied mental illness, and when psychiatric casualties appeared in large numbers during the North African campaign, their reactions were appropriately dramatic and bizarre. Exploratory efforts were then made to re-establish the WW I system of forward treatment for acute psychiatric breakdown. Psychiatric casualties were held in a field medical facility near the fighting for several days of treatment which consisted of sedation to ensure rest and sleep, adequate food, and opportunities to bathe, shave and discuss their experiences. As was found previously in WW I, a large proportion of cases could then be returned to combat duty. ${ }^{14}$

\section{"Exhaustion"}

The new terminology for psychiatric casualties was shortly thereafter officially established as being "exhaustion", a label which more aptly fitted the war of movement and physical fatigue that was WW II as opposed to the static type trench warfare of WW I. The simplistic generalisation that "every man has his breaking point" became almost universally known and accepted, putting the onus now back on environmental stress and de-emphasising individual human weakness. Consequently, symptoms became less dramatic, with patients signalling fa- tigue, tension, tremor or irritability. ${ }^{15} \mathrm{~A}$ positive impact of this change in label and symptoms was that it facilitated early, prompt treatment, reduced the stigma of mental illness, and allowed for an early return to duty. ${ }^{16}$

As with the "shell shock" of WW I, it became increasingly apparent that "exhaustion" was mainly psychologically induced. Psychiatric casualties were nonexistent from troops who had advanced for days against enemy opposition, despite the presence of severe physical damage. Conversely, many psychiatric casualties occured just prior to, or in the early phases of combat where there was little opportunity to develop physical fatigue. The essential element in breakdown was thus the immediate and continued threat from battle danger, while physical fatigue or recurrent illness reduced the ability to maintain adaptation under battle conditions. ${ }^{17}$

While there was a larger incidence of psychiatric casualties amongst the "new" rather than "old" members of a combat unit, an "old Sergeant Syndrome" became identified as occuring even in those with good or superior combat records. These soldiers suffered from self-blame and loss of self-esteem from inability to control their behaviour in combat. It was evident, however, that rotation from combat would have prevented this. ${ }^{18}$

\section{Experience in Korea and Vietnam}

Conceptually, what emerged from the Korean War was the distinction of "combat exhaustion" as separate from exhaustion due to physical fatigue. An expanded psychiatric service, the supportive "buddy system" and a rotation policy of nine months in combat seemed to be responsible for the low level of combat-related psychiatric casualty rates, which in the latter phases of the war reached levels not much above those prevailing in noncombat areas. ${ }^{19}$

Initially, at least, the incidence of psychiatric casualties in the Vietnam conflict was also remarkably low. In the early years of the war adequate training, equipment, leadership and medical evacuation all helped to keep morale high and thus to reduce susceptibility to combat stress. The brief, episodic nature of combat operations was also condusive to military efforts to provide frequent periods of rest and recreation. Particularly important too was the predermined one-year tour of duty. For the American soldier, 
the knowledge that if he could merely survive until a specific date his removal from combat was assured enabled him to accept and manage stressors that might otherwise have been incapacitating. A serious drawback, however, was that unit identification and cohesion was undermined by the varying individual rotation schedules. ${ }^{20}$

In the later years of the war, the incidence of psychiatric casualties went up steadily as moral declined, combat took on a more traditional mold, and more soldiers returned for more than the one-year tour. Other forms of psychopathology became prevalent, including drug abuse, insubordination, inter-race friction, even nearmutiny and the "fragging" (murder) of officers. In Kormos' view, these novel and unconventional forms of psychopathology more than made up for the low attrition rates registered if only combat exhaustion is taken into account. Taken together with the large number of administrative discharges (often a convenient method of dealing with soldiers who otherwise would receive psychiatric treatment), the question is raised as to whether an epidemic of conventionally defined combat stress reaction had been prevented only at the price of an epidemic of character disorder. ${ }^{21}$

\section{The 1973 Arab-Israeli War}

Ingraham and Manning note that the usefulness of the "exhaustion" label ended in 1973 when the Israeli army sustained large numbers of psychiatric casualties in the first two days of intense fighting - much too soon to fit the classical pattern of "exhaustion" following 30 days or so in the line. ${ }^{22}$ The symptoms exhibited were similar to the exhaustion syndrome, but the "exhaustion" label was not credible to either the patients or their commanders. The neutral terms of "combat reaction" or "stress reaction" were thus adopted as a diagnosis. Israeli findings were that all personality types appeared equally vulnerable to combat reactions; compared to other soldiers the casualties performed equally well in combat and were as often decorated. Psychiatric attrition was highest during the early days of combat, as the troops went through a phase of adaptation. The rate then levelled off only to rise again in what has been called the phase of exhaustion. ${ }^{23}$

\section{Overview}

From the historical perspective, Ingraham and
Manning make the point that there is no simple set of symptoms common to all wars and all combat psychiatric casualties. ${ }^{24}$ The influence of labelling is evident, and these casualties are "psychiatric" in the sense that they are physical and mentally unable to function as soldiers in the line althouth apparently suffering no organic damage. Seldom are they "crazy" or "schizoid" but with appropriate attention they are recoverable manpower.

A persistent problem, as Glass points out, is that under the stress of battle, the formal rates of hospitalisation do not begin to include all adverse psychological reactions to combat. Undiagnosed stress disorders could well include many complaints of back pain, digestive upset, heart palpitations and recurring pain from old wounds or surgical scars. Those lightly injured in action, absent without leave from battle or with self-inflicted wounds could also be "hidden" psychiatric casualties. $^{25}$

Noting the confusing variety of symptoms, syndromes and behaviours, Kormos has proposed the neutral and all-emcompassing term of "Acute Combat Reaction" as referring to "all psychopathology associated with combat ... (and) signalling that the soldier, although exepted to be a combatant, has ceased to function as such". ${ }^{26}$ The essential element in all Acute Combat Reactions is the rejection of the role of combatant. Deciding whether this rejection is due to unwillingness or inability leads to a choice between medical-psychiatric and administrativedisciplinary actions

The unconventional forms of phychopathology noted earlier in Vietnam need also to be seen as Acute Combat Reactions since they include the common element of a rejection of the role of combatant eg. drug use offered the self-administered equivalent of temporary psychological removal from battle, while assaulted officers were often those who had shown more zeal in the pursuit of combat than their men found tolerable. Kormos' valuable insight is that the underlying psychological function of such behaviour is essentially analogous to that of other more conventional combat stress reactions. The presenting symptoms are different, but the precipitating conditions are similar and thus amenable to similar preventative strategies. 


\section{HAGAR the Horrible}

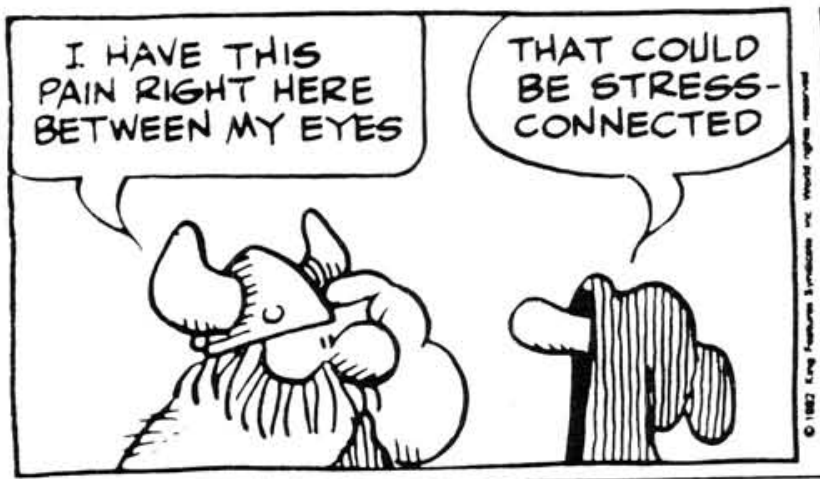

\section{Physiological and Psychological Stress Reactions to Fear}

It has been noted that the fear of unexpected death in wartime is unlike any other stress one can ever experience. It affects the soldier in a myriad of ways both physically and emotionally. He either learns to adapt to the difficult stresses of the new reality or he begins to maladapt and to decompensate. Adding to the stress of the situation are conflicting fears such as of becoming so fearful as to be totally unable to function or of losing face within the combat group. Basic instinct calls for either concealment or flight, while the social urge to remain part of the group and do one's duty prompts standing in place. ${ }^{27}$

Belcher points out that fear is a natural, emotional reaction to what appears to be a radically unfit or unfriendly condition or environment. ${ }^{28}$ While terror is fear at its greatest degree, fear at any stage manifests itself physiologically by way of changes within the human body. Normal indicants of combat stress include: muscular tension, shaking and tremor, perspiration and digestive, urinary, circulatory and respiratory system reactions. In a mild form, such symptoms are normal among combat troops and can be considered pathological only when become severe enough to impair efficiency or persist inappropriately when the stress of battle is no longer indicated. ${ }^{29}$ As General Menninger once observed, psychiatrists in war are treating normal reactions to abnormal situations. ${ }^{30}$

It is unwise, however, not to make certain distinctions in the case of psychiatric casualties. Strange, for instance, has identified three categories of combat-precipitated psychiatric syndromes, for each of which there is a different prognosis and method of treatment. ${ }^{31}$ What he

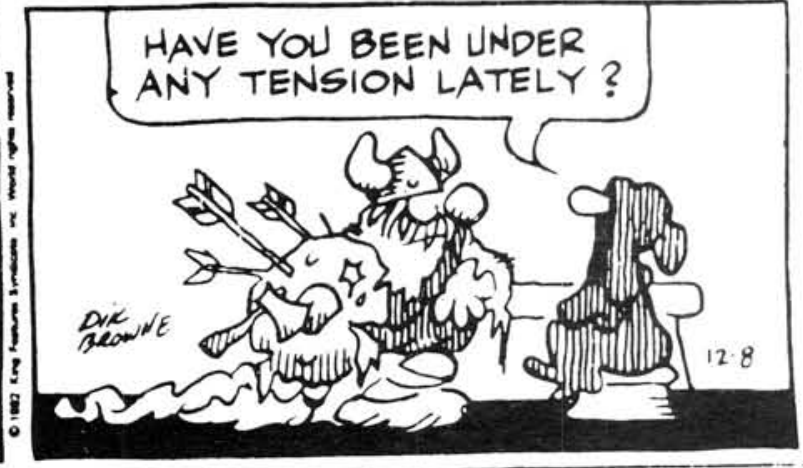

terms "combat fatigue" is seen as the transient pathological reaction of a basically healthy personality to severe stress of combat. In contrast, "pseudo-combat fatigue" covers those with preexisting personality disorders who developed overt symptoms in the battle environment, and "combat neurosis" encomposses patients with a chronic psychoneurosis which had not been previously noticed. In all three cases the presenting symptoms are the same, but the combatfatigue cases have the brightest prognosis for return to duty since their treatment is shorter and less deep.

Another medical difficulty is in identifying acute anxiety symptoms from actual physical illness. In WW I, for example soldiers complaining of tightness in the chest, difficulties in breathing and pounding hearts could either be suffering early symptoms of chemical attack or normal fear reactions to combat. Similarly, effective medical treatment in WW II required that soldiers suffering from fever, weakness and uncontrollable trembling be properly sorted out into malaria victims, heart exhaustion cases or psychiatric casualties. $^{32}$

When confronted with sudden danger approximately 75 per cent of people can be expected to be ineffective temporarily for an appreciable time. ${ }^{33}$ With prolonged exposure to life-threatening stress, however, studies have shown that varying coping mechanisms came into play. Such studies have demonstrated that while there are indeed somatic changes in response to the combat environment, these have not been of the magnitude that might have been expected. ${ }^{34}$

In order to account for the relatively low levels of endocrinological indicants of physiological stress response in the face of a clear-cut threat 
of death of mutilation, it has been argued that altered perception of such a situation becomes a necessary and indispensable method of adaptation. Varying psychological defenses are used to exclude overwhelmingly threatening events from conscious appreciation, and in so doing control the endocrinological response to stressful situations. These defenses enable the man to perceive reality in such a way that he minimises the danger it represents, as well as creates for himself a feeling of invulnerability and omnipotence. "Switching off", or psychological anaesthesia, is perhaps the most effective psychological adaptation technique. Overall, it appears that accurate and objective intellectual assessment of the environment is sacrified in order that the individual can maintain his physiological functions within a certain limited range. ${ }^{35}$

Further studies have shown that endocrinological response to danger are significantly influenced by social factors of group consensus and support, while higher levels of steroid secretion have been traced to the stresses of the leadership role and its obligations. ${ }^{36}$ There is, in fact, evidence to suggest that interpersonal stress in the form of social demand of assigned leadership role exerts a more powerful effect upon certain physiological parameters than does an objectively life-threatening situation. The latter circumstance can presumably be more easily dealt with at a psychological level. ${ }^{37}$

Overall, as Bourne points out, both physiologically and psychologically man is able to adapt to the stress of war ${ }^{38}$ At least when the episodes of combat are relatively brief and other physical needs such as nutrition, warmth and sleep are adequately met, the potential danger presented by the possibility of death in battle can be defended against psychologically over relatively long periods of time.

\section{Correlates of Psychiatric Attrition}

Field observation, research and clinical studies have shown psychiatric attrition from battle to be a corollary of a number of factors:

1. Combat conditions - those soldiers exposed to actual combat are more likely to become psychiatric casualties than those who are not, while a significant relationship has been shown to exist between actual danger and the incidence of combat neurosis. Psychiatric casualties can be expected to rise with the

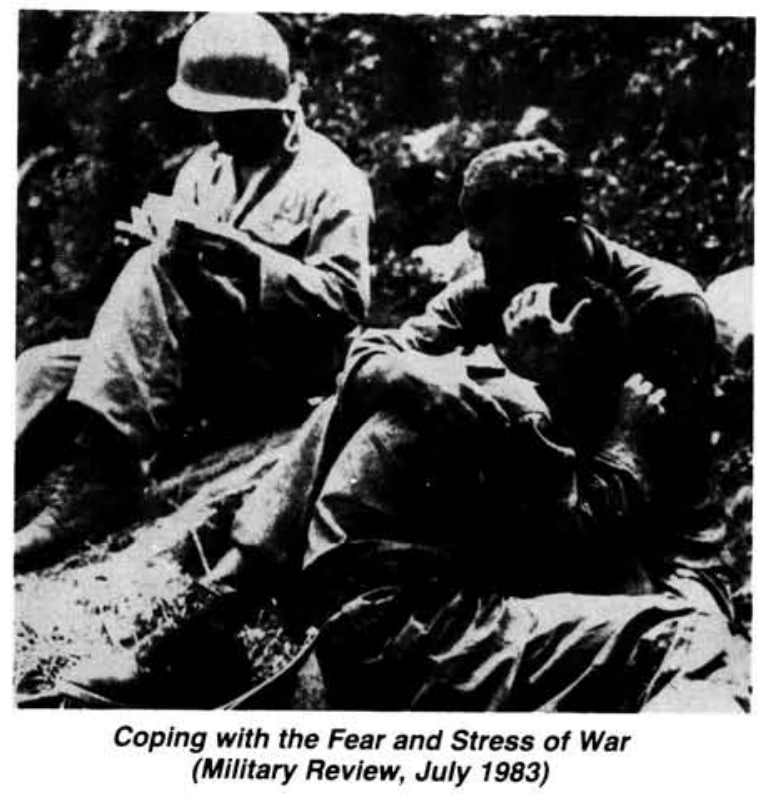

intensity of combat, an approximate ratio being one such casualty for every four battle casualties. The consensus of a number of reports and studies is that an average soldier can sustain between 80 and 100 aggregate days of combat before being rendered ineffective by combat stress reaction.

Psychiatric casualties occur predominantly when the lines of battle are static and diminish sharply when the troops are on the move, even though they may be in full retreat. Particularly stress-inducing is artillery or other bombardment without any effective method of retaliation. Overall, however, Tischler's conclusion is that a majority of individuals do appear capable of adaptation under combat conditions although very few veterans have ever admitted becoming "used to it" or immune from its terrorising effects. ${ }^{39}$

2. Non-battle factors - isolation, extremes of weather, monotony, inadequate diet, lack of comfort, excessive physical demands, and illness, have all been significantly implicated as contributing to emotional breakdown even in relatively low hazard situations. ${ }^{40}$

3. Predisposing psychological factors - the precise relationship between predisposing factors and the "breaking point" has not as yet been determined, with various studies giving conflicting findings. The consensus of investigators, however, is that men with histories of either severe emotional deprication and frustration during childhood or of prior maladjust- 
ment in family, school, work or the community are less likely to render effective military service and more likely to be vulnerable to hazard and privation conditions. ${ }^{41}$ Nevertheless, as Kordiner has observed, a war situation can not only revive pre-existing syndromes heretofore dormant, but can also create new ones. Indeed, "no one exposed to war experiences comes away without some of the symptoms of the traumatic syndrome, however temporary they may be". ${ }^{42}$

\section{Factors Mitigating against Psychiatric Attrition}

Studies conducted during WW II revealed that the single most important mechanism for sustaining the individual soldier during the stresses of combat was the primary group. ${ }^{43}$ In the presence of a small group of cohesive and supportive men, the individual combat soldier withstands danger and deprivation which, if experienced on his own, would prove overwhelming. As Ingraham and Manning point out, the number of psychiatric battle casualties is related more to group characteristics than to personality traits. ${ }^{44}$

A broader concept is that of morale, a factor which has generally been credited both with increasing combat effectiveness and with decreasing the frequency of psychiatric attrition. Tischler notes that the term morale refers to the collective state of motivation existing within a group. This results from the interaction of a number of factors, including effective leadership, group cohesiveness, the knowledge that adequate rewards will be forthcoming for individual and group efforts, and a sense of purpose ${ }^{45}$

Morale is further enhanced for the individual by factors such as the quality of his training, the reliability and vintage of his weapons, and the quality and availability of medical care should he be wounded. A further support is that of religion as well as of a belief in the justice of the cause and a knowledge that the might and the resources of his nation are marshalled in his support.

The general health and physical fitness of soldiers serves also to improve tolerance to the stresses of combat, as does periodic rest and recreation, and a rotation system.

Apart from the above preventive factors, the proper medical treatment can convert psychiatric casualties into recoverable manpower. The paradox here, as Ingraham and Manning point out, is that the more such casualties are treated like hospital patients, the worse they get. Historical experience suggests that for those evacuated to the rear the prognosis for a return to duty is very poor, compared to those treated near the front. ${ }^{46}$

Current US Army medical doctrine has three treatment principles: "immediacy, proximity and expectancy". What these entail is that the patient should be treated as soon as possible, as close as possible to the location where the symptoms started, and with the expectation that he will shortly return to combat. The logic behind these principles is that their use very often eliminates or minimises the secondary gains from illness and the chronic symptomatology that would otherwise ensure when men are sent to the rear to undergo prolonged psychiatric hospitalisation. $^{47}$

Various writers have objected to the above treatment principles on the grounds that they are harsh and heartless. Kormos, for instance, contends that they are more preventive than curative ${ }^{48}$ It has also been pointed out that unlike the indepth conventional therapy, the emphasis is of a more shallow, "patching up" nature, focussing on the immediate past (battle) and the immediate future (return to battle.).

Perhaps the best counter to this sort of argument can be found in the practical field experience of General Richardson. ${ }^{49} \mathrm{He}$ argues that it was only when the soldier could be dealt with on the spot, while the dangers and fears from which he was unconsciously seeking to escape were still operative, that his still fluid emotional reaction could be moulded into a desirable form before it set in the shape of conversion hysteria or neurotic illness. Once that had occured it might take weeks of not always successful effort to destroy the pattern which had set firmly, and to restore selfconfidence. A quick return to duty thus serves both the individual and the Army.

\section{A Conceptual Framework}

Tischler has analysed the factors influencing the rate of psychiatric attrition as falling into two major categories, namely:

1. Stressors - stimuli that strain an individual's adaptive resources, and 


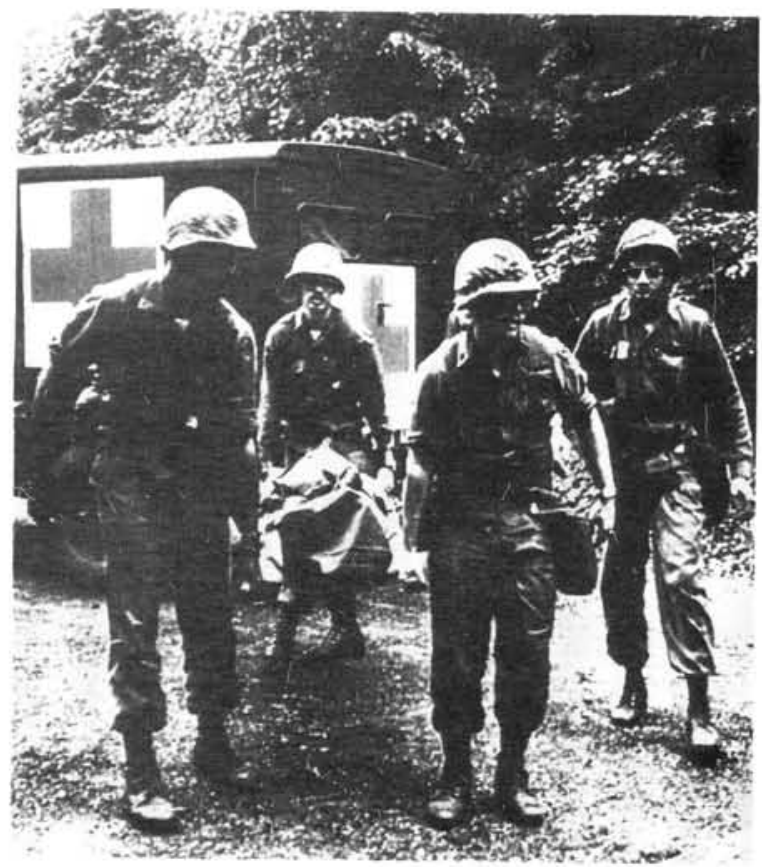

An approximate ratio of 1 psychiatric casualty for every 4 battle casualties can be anticipated (Army, September 1983)

2. Resources - supports or sustaining influences that strengthen an individual's adaptive capabilities. ${ }^{50}$

In general, emotional breakdown is conceptualised as resulting from an imbalanve between environmental stressors and resources. More specifically, each man has particular tolerances and specific resource requirements. The balance between the two is determined by the personality structure of the individual. If this balance is disturbed, either through an increase in stressor intensity or a decrease of available resources, then the signs of overt and covert psychiatric illness will begin to emerge. Various military discipline problems can also be seen as reflective to a certain extent of such an imbalance.

As can be seen, this is a much more comprehensive view than the one prevailing throughout much of WW II that breakdown was primarily a functon of personality defects. The shift has been from a predominantly clinical orientation to a broader concern with the management of men, including such important factors as the stress and support balance in the environment, leadership and group morale. ${ }^{51}$ What this sort of view implies is that the onus for the psychiatric casualty or stress-induced maladaptive behaviour is placed at least partly in the hands of command, and this is where preventive strategies need to be planned and instituted.

\section{JOB-RELATED STRESSES IN THE MILITARY}

While combat-related stresses are certainly the most extreme and troubling for the military, this is not to overlook the very serious stresses to be found in the noncombat branches of the military i.e. the budgeting and support services, which often take up a bureaucratic form. As Zais and Taylor point out, these job-related stresses experienced in the military are similar to those in industry. ${ }^{52}$

The most stressful job factors would include heavy workloads and demands, time pressure and unrealistic deadlines, lack of feedback on job performance, interpersonal conflict and poor supervision, role conflict and ambiguity, and organisational change ${ }^{53}$ The principal difference with industry, according to Zais and Taylor, is that task overload is the norm, is not engendered by a profit motive, and receives no protection from such devices as labour unions. ${ }^{54}$ Furthermore, there are the tensions associated with the sometimes illfitting co-existence of traditional military hierarchy and discipline with professional competencies and managerial principles of effeciency.

Clyde Smith has identified the field of logistics as one exerting particular stress on military personnel. The logistics manager is very much the man-in-the-middle, with downward stress generated by superiors, upward from subordinates, and laterally from associates and peers. Job requirements and deadlines sometimes necessitate working evenings and weekends, creating consequent tensions and prolems in personal and family life. ${ }^{55}$

Another highly stressful field is that of military intelligence, where individual personnel often shoulder great responsiilities and a loneliness stemming from undercover work and the handling of highly classified and sensitive information. Brian Chermol notes too the stresses which aviators do not share with their land-based peers in that they must perform complex manipulation of aircraft control elements in threedimensional space.$^{56}$

Each particular branch of the military obviously has its own unique stresses; the urgency of dealing with them may be gauged in the decreased levels of satisfaction and an alarming exodus of experienced midlevel officers and noncommissioned officers. All this is in addition to the price 
paid in terms of mental and physical health, a price often surprisingly higher than that of industry or even in the more combat-orientated arms of the service.

\section{LIFE-STYLE STRESSES IN THE MILITARY}

Zais and Taylor note the particular type of stress which stems from certain unique aspects of the military lifestyle. ${ }^{57}$ These include frequent uprooting of families and their transfer from military base to military base; frequent changes of jobs, bosses, subordinates, communities, friends, schools, churches, and other sources of socioemotional support; and the common occurence of famly separations when husbands are on duty, overseas, at sea, or on manoevres.

Another significant stressor which has been noted is the inherent regimentation of the military system in which the work environment and most aspects of barracks life for single soldiers, as well as certain aspects of family living in Army communities for married soldiers, are closely prescribed by military regulations. Examples of stressors unique to military regimentation are reveille formation in the morning, rigorous inspections of quarters, certain aspects of ceremonial military formalism etc. ${ }^{58}$

Military workdays and workweeks are also openended and highly dependent on the accomplishment of the unit mission. Traditionally, the time demands of a soldier for the family or for leisure have been considered secondary to the mission. Some modern writers have, however, decried what they see as the present-day attempt to recruit new members on the basis of comfortable, secure job rather than a self-sacrificing calling or vocation.

\section{PREVENTIVE AND ADAPTIVE COPING RESPONSES TO STRESS IN THE MILITARY}

As has thus far become evident, negative reactions to stress in the military have complex multidimensional causes and effects. Preventive measures can thus be expected to have wideranging implications for all aspects of military policy. Inasmuch, however, as the ability to constuctively utilise and cope with various orders of stress relates positively to the all-encompassing aim of military effectiveness, the issue needs to be squarely faced.

What will be dealt with in this section are some of the areas in which the military can seek to make the most of what supportive elements are available as well as minimise stress that is self-defeating or unproductive. The interdependence of these elements needs to be appreciated to the extent that inattention to one aspect may undo what has been achieved due to the other elements. Areas covered include the wise use of rest and leave, acclimatisation, personnel selection, measures to encourage cohesiveness, stress utilisation in training, and the related issues of leadership and discipline.

\section{Rest and leave}

One of the most important and most widely recognised measures for the prevention of a combat stress disorder is the wise use of rest, especially during prolonged periods of combat. Even men who are beginning to breakdown, to "crack", can be saved from a complete nervous breakdown if they can be withdrawn from the combat zone and allowed to rest and sleep.

As Richardson points out, those best equipped to spot the first warning signs are the individual soldier's own comrades and NCO's of his section and platoon. ${ }^{59}$ Care should be taken, however, to distinguish between men who are simply afraid and those who are beginning to find fear uncontrollable. The danger is that of a snowball effect if too many are sent out of battle simply because they were showing the physical signs of fear. Richardson's view is that while there is nothing to be ashamed of in feeling or even showing fear, one cannot condone giving way to it. ${ }^{60}$

Langtry considers the importance of recuperation to be such that it can have a direct bearing on the selection of tactics eg a 20-minute spell at the end of an attack, should the tactical situation permit it, will go far in restoring confidence and physical capacity. ${ }^{61}$ Ideally, one group should be required to tackle but one combat task in a battle sequence. Based on experience, it has been recommended that a commander should attempt to ensure that everyone, including himself, gets a minimum of 6 hours of sleep every 24-hour period. Anything less than this will lead to serious degradation in performance. ${ }^{62}$

Combat effectiveness can also be extended if soldiers are hopeful. As Forster points out, leave and rest periods, if known to be immutable, can supply such hope, without which despair may set in and stress-sustaining morale collapse. ${ }^{63}$ 


\section{Acclimatisation}

Acclimatisation has been defined as the natural process of physiological and psychological adaptation by the body to enable it to cope with the stress imposed under adverse climate conditions. ${ }^{64}$ Since it is possible to acquire it positively, it is worthwhile striving to develop the highest level of acclimatisation to combat the worst effects of the environment. Not only does such acclimatisation enhance tolerance of hard labour in heat and high humidity, it also enhances performance at lower levels of climatic stress.

Various techniques are available to speed up the process of acclimatisation, but as Langtry has argued, it is a command and leadership responsibility at all levels and should not be left in the hands of medical officers. ${ }^{65}$ As a back-up to acclimatisation, steps should be taken to ensure a proper diet and the maintenance of a high level of physical fitness.

\section{Personnel Selection}

Military experience has been that pre-induction screening to try to pre-clude psychological maladjustment is costly impractical, unrewarding and wasteful of scarce manpower resources. Where screening can prove useful, is in eliminating people who are overtly psychotic or markedly deviant in their social behaviour. However, since anyone subjected to enough stress can develop debilitating psychiatric symptoms it has been remarked that "if screening was to weed out anyone who might develop a psychiatric disorder, it would be necessary to weed out everyone." 66

Personnel selection as a way of fitting abilities and personalities to the task should contribute to lessening the demands on a person and thus the stress he experiences. This should definitely be the case in the non-combat arms of the military, but as Richardson has pointed out "the acid test of battle will often confound the predictions of psychiatrists". ${ }^{67}$ Furthermore, "gallant deeds have been performed by ... men whom the psychiatrists, following their own rules, ought to have rejected" ${ }^{68}$ It has been suggested, therefore, that a greater reliance be placed on identifying men with emotional and behavioural problems during the initial basic training, rather than relying purely on pre-induction screening. ${ }^{69}$

\section{Cohesiveness}

Cohesiveness is the ability of a military unit to hold together, to sustain mission effectiveness despite combat stress. ${ }^{70}$ Organisational policies designed to enhance cohesiveness and the formation of primary groups include: (1) training, deployment, and replacement of intact combat units or teams, as opposed to training individuals who are subsequently assigned to extant units; (2) encouraging junior leaders to maintain an attitude of protectiveness toward their subordinates; and (3) ensuring that members of combat units spend as much time together as possible in all phases of life, which includes housing by unit, eating by unit etc. Parades and military drill, as well as unit athletic and social activities, could also serve to foster the growth of cohesiveness within fighting units. ${ }^{71}$

Primary group cohesion, hoever, cannot be seen as enough for combat effectiveness; it is a welldocumented fact that bonds between members of primary groups can develop into a basis of opposition to the larger organisation. ${ }^{72}$ High primary group cohesiveness thus needs to be supplemented either by high unit cohesiveness or national sociopolitical commitment. ${ }^{73}$ Regimental newssheets, distinctive uniforms, badges etc. could serve to confirm loyalty to the regiment, while lectures explaining and justifying the justness of the cause could serve to gain the necessary ideological commitment.

Forster notes also that the soldier's membership of other groupings such as his family must be fostered if he is to receive the support from home that will keep him committed wholeheartedly to soldiering. It is for this reason that welfare services are so important, why leave should be sacrosanct rather than a retractable priviledge, and pay reasonable for the job. ${ }^{74}$

\section{Training}

It has been pointed out that it is in the field of training that we can make the most progress in peace-time to avert the stress of war. Particulary important here is stress inoculation training, in which ideally, the trainer identifies all the stituations likely to afflict the soldier in war, reproduces them in training and shows him an active way of solving the problem. By reducing the unknown and the unexpected to a bearable minimum, self-confidence is fostered which can serve as a basis for endurance, self-discipline, self-respect, courage and good humour. ${ }^{75}$ 
At the lowest levels, the soldier's personal skills (weapon handling and cleaning, fieldcraft etc) should be repeatedly practised so as to become automatic. Recent social-psychological research has confirmed that the performance of underlearned tasks or new skills is impaired by stress, unlike the performance of overlearned tasks and skills. ${ }^{76}$ Belcher considers too that a fighting man's wartime responsibilities should be an automatic ritual such that obedience is instinctive and concentration on his work precludes dwelling on his plight. ${ }^{77}$

Forster notes that opinion is divided about the value of more indirect training. ${ }^{78}$ Foot drill, for instance, may indeed engender esprit de corps and rigid discipline but armies which do not emphasise it have proved their fighting worth. On the other hand, an orderly field routine, although mundane, does ease the strain of living in a combat environment. An important adjustive response to stress is distraction, and even the oft-derided "bull" - defined as "excessive insistence in military administration on the specious and showy, rather than on things really contributing to military efficiency" - has successfully served this role, particularly where boredom could undermine morale. ${ }^{79}$

\section{"Mental training"}

Apart from physical training to increase the soldier's resistance to physical strain, Richardson has emphasised the importance of "mental training" to raise his resistance to the nervous mental strain of war. ${ }^{80}$ Attention is paid here to instilling pride in the military profession and regimental history, chaplain's periods for building character and developing values, and in general preparing soldier's minds for war.

More directly, the subject of fear and stress reactions in battle should be brought out into the open for examination and free discussion. Informal short talks with free discussion are preferable to lectures. The aim is to ease the fear of the unknown by giving warning of the normal physiological and psychological reactions to fear. Unclouding any myths or misperseptions surrounding the enemy is also important.

A widespread understanding of the true nature of the psychiatric casualty can furthermore play a role in prevention, especially since as Richardson points out, psychosomatic symptoms often occur as an unconscious escape mechanism offering an honourable way out. ${ }^{81}$ Fear of the ridicule of fellow-soldiers could then have preventive value, although soldiers must be taught to recognise the early warning signs of genuine distress in each other so that appropriate rest and recuperation measures can be prescribed. Unfortunately, differentiations will never be easy. The best that can be hoped for is at least a rough balance between ensuring that "escape is not so easy as to precipitate epidemics, and minimising the stigma of genuine breakdown as that reintegration into the unit is facilitated after treatment.

\section{Stress utilisation}

The whole issue of how stress should be utilised in training is one that has attracted considerable controversy. Current US Army Training and Doctrine Command (TRADDC) philosophy related to stress is as follows:

- Only stress that directly results from the trainee's performance of tasks will be allowed. The stress will be positive, cumulative, challenging and oriented toward goals that are attainable.

- Nonproductive stress created by physical or verbal abuse will be prohibited.

- The operative philosophy is to train soldiers by building on their stengths and shoring up their weaknesses. It is not to "tear them down and build them up again", although high standards will be insisted on. ${ }^{82}$

This philosophy has been sharply attacked by US Army Captain Barlotta, who argues that applying maximum physical and mental stress builds character and prepares a person for the hardships of war. The use of negative motivation is seen as necessary, while he contests what he sees as the prevalent conception that almost any type of negative stress leads to abuse. Overall, he decries what he sees as the misconception that the Army can be managed instead of led and that the new soldier no longer needs to be trained under stress or disciplined. ${ }^{83}$

So far as his views on stress are concerned, Barlotta overstates his point. Certainly, he is correct to argue that stress in training cannot only be "positive" and solely related to task performance since it is the overpowering negative stress of combat which the soldier must be trained to withstand and operate effectively in. However, as Forster has pointed out, there is a limit, and battle simulated or other harsh stress be aimed at self-confidence rather than breaking a per- 
son's spirit. Should this latter occurence happen, the whole object of the training would be defeated, since limited exposures to stress situations are likely to be helpful mostly in that they will prove to the soldier how much more he can endure than he had believed possible. ${ }^{84}$

Barlotta seems furthermore to come close to denying that stress in training could ever be unproductive or abusive. Giving full rein to his "all stress goes" philosophy would inevitably lead to resentment and primary group bonds that in all likelihood would combine so as to "gyppo" rather than wholeheartedly go along with what is seen as tough but necessary and fair.

The following considerations are suggested in helping to decide whether a given type and intensity of stress is helpful and necessary to the overall cause of enhancing morale and selfconfidence:

1. Is it deliberately belittling, demeaning or injurious to human dignity?

2. Is it obviously peripheral to military goals perceived as such and patantly malicious or a way of "getting at" trainees?

3. Will it break a man's spirit instead of giving him the selfconfidence that comes from having tested, but not gone past his limits of endurance? If the goal is explicitly that of selection, then searching for weak links would justify an extreme maximum order of stress, but for the training of the general soldier this is unacceptable and counterproductive.

4. Does it alienate, demotivate and form resentments? Common sense and feedback should be a good guide here, but examples would include demanding push-ups before giving mail from home, and "on-off" game playing as regards the granting of leave. If leadership authority is abused in this way, it can only lead to disrespect.

5. Related to (4) is whether the stress imposed crosses the borderline into the sphere of abuse. As Barlotta has rightly claimed, abuse is a nebulous area, and he gives the example here of an NCO pulling or pushing a trainee so as to force him to finish a road march rather than drop out.$^{85}$ his point is taken, but a clearant case would be if were say, brutally kicked forward.

The above guidelines are, of course, ambiguous, but their worth should be seen in that they sensitise to the issues involved. Kindness and a misplaced humanitarianism is not what is needed when training for the brutal reality of war. Neither, however, is an "anything goes" indiscriminate stress maximisation policy that looks set to producing resentful, automaton-like soldiers unable or unwilling to take the initiative beyond their strict orders.

\section{Leadership and Discipline}

A related aspect of Barlotta's attack is his advocation of a harsh, almost blind, discipline in order to get real efficiency. He sees no reason for the Army to become "liberal" simply because society has changed, but rather, it must be "a bastion of discipline in an ever-changing permissive society."

The extremeness of Barlotta's stand can be traced to two related misconceptions. Firstly, modern-day adaptations in training methods can be seen not so much as a "liberalising" or "softening" but rather as the better use of human resources, including individual initiative. Secondly, there is a need to re-evaluate leadership techniques in the light of what it now takes to capture morale and loyalty in modern-day society.

Langtry notes a number of general socio-political factors which will impact increasingly on leadership techniques. Subordinates will increasingly tend to make their own judgements and to challenge articulately any expression of "their's not to reason why" form of authoritarianism. They will want to play a part in the formulation of military education and training programmes, and to contribute to the development of tactics, strategy and defense policy. Consequently, there will need to be a more realistic and intelligent attitude towards the giving of and obedience to orders, and wherever practicable, this should give rise to more informality, rather than less discipline. Leaders at all levels thus need to become increasingly sensitive to such fundamental pressures for change, which should include the scepticism of more educated soldiers. ${ }^{87}$

Perhaps the Israeli Army is best indicative of how modern armies can adapt so as not to capitulate before such pressures of change but turn them to advantage. Rolbant notes that the concept of discipline in the Israelli Army is limited to the need for unquestionable obedience in executing orders, while dispensing with the sym- 
bols of submission. He argues that while these may be necessary ingredients of military life, they are vital only when there is a great discrepency between ranks as regards motivation, orientation and courage. When rank denotes greater responsibility, and is not accompanied by a differential willingness to fight, discipline becomes meaningful as an aspect of higher productivity rather than domination. ${ }^{88}$

The objective of the Israeli military is not to eliminate differences in rank and authority, but to seek to maximise participation in implementing devisions at all levels, by taking into consideration the technical skills of all concerned. The officer is taught to temper his command with explanation, without opening the way to fruitless argument. Manipulation and group concensus thus blend naturally with narow differences in privileges, style and uniform.

Rolbant argues that direct and rigid discipline is the best control only with a military establishment employing close-order formation and consisting of conscripted masses with a relatively low fighting spirit. This is, however, also their principle weakness, since advanced miltary technology continuously throws the solitary soldier or the single tank upon his or its own resources and those of the immediate comrades. The technology of warfare has in fact become so complex that the co-ordination of a complex group of units cannot be guaranteed simply by authoritarian discipline. ${ }^{89}$

Overall, the example of the Israeli Army is important in that it illustrates how the harsh, rigid and authoritarian traditional discipline of the military can become counterproductive in modern warfare, and that adaptive leadership techniques more consonant with the values of modern society can prove advantageous in tapping the individuality and talents of all. Similar adaptational changes regarding discipline and leadership could prove crucial in keeping the Army in step with modern society without compromising efficiency but also reducing a potent source of stress originating from the disjunction between civilian and military values. As Montgomery once pronounced "the Army must be woven into the social fabric of the Nation." 90

A point of note here is that Lord Moran observed some four decades ago the differences between the discipline of persuasion and the discipline of punishment, and that the latter discipline was out of place in the society of the time. He war- ned, however, that discipline, which is control from without, could only be relaxed safely when it was replaced by something higher and better, namely the control from within that came from morale. ${ }^{91}$

Overall, it is as well to remember the military will always remain somewhat isolated from the values of the society it protects. Essentially, the combat arms of the military cannot be run on ordinary business principles, and while there are possibilities concerning what type of discipline could prove most effective given both advanced technology and more intelligent individualist recruits, there can be no argument but that this discipline will have to be firm and tough if the exceptional psychological rigours of combat are to be endured. The dilemma is that while the military cannot afford to remain aloof from social forces in society, neither can it give up certain central values derived from the need to cope with extra-ordinary demands which require a measure of self-sacrifice and restriction of individual freedom.

\section{Post-Combat Stress}

Impressive evidence has been marshalled to support the belief that delayed stress reactions may occur many months after discharge from combat. The term "post-Vietnam syndrome" was indeed coined so as to indicate the particular stress reactions and pressures for adaptation faced by the returning Vietnam veteran. It thus seems reasonable that as part of the military's responsiblity to society, various going support and councelling services should be available for the discharged servicemen should he so require it. Furthermore, there are several important axioms which have evolved from the experiences of other wars regarding strategies for facilitating the veteran's homecoming and transition from the battle zone. As observed by Borus, they include the following:

1. helpfulness of gradual rather than precipitous transition from combat to non-combat status;

2. need to reorient combatants to the different roles and routines of civilian life;

3. the need for formal and ceremonious acknowledgement to the soldier and his significant others of his change in status;

4. the helpfulness of the immediate group or small unit in sharing experiences and facilitating readjustment;

5. the need to prepare and forewarn the vete- 
rans of the stresses associated with this transition;

6. the need to make the continuing noncombat role meaningful to the veteran. ${ }^{92}$

\section{Coping with job-related and military life- style stresses}

In the non-combat related arms of the military, stress management can follow the more conventional lines employed in industry. Clyde Smith suggests that in order to reduce stress, managers can:

- Prevent unrealistic deadlines by thorough planning.

- Avoid overloading subordinates with excessive, nonessential work demands.

- Ease time pressures through equitable task distribution.

- Prepare subordinates for changes to minimize anxiety

- Provide job performance feedback.

As individuals, we can:

- Establish daily goals and priorities.

- Manage our time effectively.

- Delegate authority and responsibility.

- Withdrawn temp̄orarily from overly stressful problems and return to them later.

- Spend 10 to 15 minutes daily doing relaxation exercises.

- Allot daily rest and relaxation time.

- Participate in a regular physical activity programme.

- Ensure adequate rest and nutrition daily. ${ }^{93}$

Two other suggestions, namely to engage in non-work-related activities and to separate job and family life, could cause problems if the military is seen as a vocational calling rather than a mere job. This is, however, part of the self-sacrificing military ethic and in any case, it is unrealistic to think that all stress penalties may be avoidable.

With regard to military life-style stresses, it needs to be acknowledged that there are many traditional military supports. Formal support systems include military psychiatrists, psychologists, social workers and chaplains. Various formal and informal strategies are utilised to deal with the stress associated with relocation. The informal socio-emotional support systems are summarised in the adage, "The military takes care of its own". New arrivals in a military neighbourhood are sought out and welcomed, while military units go to great lengths to ensure that recently assigned personnel feel welcome, comfortable, wanted and supported..$^{94}$

Formal organisational practices are designed to foster unit cameraderie and a sense of cohesiveness. These practices could include monthly parties held specifically to welcome new organisational members and to honour departing members; change of command and welcoming ceremonies; and formal calls to the home of the new commander or boss. Readily available sports facilities as well as specially allocated time to indulge in sports could provide outlets for stresses that might find relief in less constructive ways. Overall attention to and maintenance of these traditional military strategies should enhance the supports available for dealing with military life-style stress.

\section{CONCLUSION: A STRESS MANAGEMENT PHILOSOPHY FOR THE MILITARY}

Identification and understanding of the multi-dimensional stresses and possible supports in the military should ideally lead to the formulation of a comprehensive stress management philosophy. Such a philosophy should firstly take due cognisance of the fact that stress can at best be accommodated or managed rather than eliminated. Indeed, as has been noted above, the controlled utilisation of stress in training can better serve to prepare soldiers for the exceptional stresses of combat.

Along with an increased appreciation of the environmental nature of stress breakdown should come a greater accountability for such on the part of leadership. Suspiciously high rates of stress-related disorders should thus automatically lead to an investigation, while leadership evaluation should also note this factor. Furthermore, the sometimes rather strained relationship between command and military psychiatrists should give say to greater communication and co-operation. As was once stated in WW II "psychiatric casualties are not in hospital because psychiatrists wish to make them patients, but because officers have failed to make them soldiers"

A greater openness and discussion of those elements which bear on the likelihood of psychiatric casualties occuring should have positive results 
in their prevention. In this connection, Richard Gabriel notes that the Israeli Defence Force's creation of an integrated organisational structure for dealing with battle stress at the combat-unit level amounts to a revolution in the field of applied military psychology. Psychological units conduct frequent attitudial surveys among troops, with questionaires being used to gauge a unit's morale, discipline, cohesion, incidence of anticipated fear, the levels of confidence that soldiers have in themselves and their leaders, and the expectations of the soldiers and unit commanders as to how they will perform under fire. ${ }^{95}$

The results of the surveys are made available to unit commanders at all levels on a regular basis, and they are also used as important elements in assessing a unit's or commander's abilities. The aim of the continual psychological analyses is to develop formulas for predicting unit effectiveness, as well as to locate any danger signs that might point to an incidence of stress casualties.

Significantly, IDF doctrine recognises explicitly that certain levels of psychiatric casualties are inevitable and are far more the result of objective battle conditions than they are of cowardice or personality traits. Accordingly, there is no particular stigma attached to psychiatric battle casualties, and this facilitates their reintegration into unit after the brief forward treatment regimen of rest and talk therapy. The myth is thus firmly laid to rest that to prepare to deal with psychiatric battle casualties need actually precipitate their occurence.

An aspect which Zais and Taylor have noted is that the Spartan ethic and the masculine ideal have impeded the military's ability to deal with its stressors effectively, especially in the direct combat arms. ${ }^{96}$ Anyone who cannot cope with stress is often viewed as unmanly, while an admission of suffering from stress-induced problems is seen tantamount to admitting incompetency or even lacking machismo. It is clear, then, that the military needs to actively counter such counter-productive attitudes by promoting a wider understanding of the nature of stress and stress-related problems.

Finally, there is the challenge presented to the military by its interaction with the changing social forces and technology of modern society. There is no escaping the need for constant adaptation, and to the extent that such adaptation is unsuccessful, organisational members will be subject to further stresses which could well threaten the overall aim of combat effectiveness. Intelligent and astute reassessment is now what is needed; retreating either into the hidebound formulas of the past or rushing headlong to embrace the new could ultimately prove disastrous.

*Cpl J.B. Bloom B.A. Hons completed his national service at the Military Information Bureau in December, 1983. At present he is studying for an MBA degree at the University of the Witwatersrand.

\section{References}

1. Chermol, B.H. "The Quiet Enemy: Combat Stress", Army, September 1983, p 20.

2. Cited in Isenhower, J.P., "Cohesion - Finding the Key", Military Review, October 1981, p 42.

3. Brummitt, M.J., "The Army's Ethical Dilemma", Military Review, July 1981, p 45.

4. Zais, M.M. and Taylor, W.J., "Stress and the Military", in Day, S.B. (ed). Life Stress: Vol III of a Companion to the Life Sciences, Van Nostrand Reinhold, New York, 1982, p 203.

5. Cox, T., Stress, The MacMillan Press, London, 1978, p 25.

6. Weills, C., "Stress: Can we Cope?", Time, June 6, 1983, p 56.

7. Smith, C.W., "Stress in Logistics - Will you become a Casualty?", Army Logistician, July-August 1982, p 12.

8. Bourne, P. Men, Stress and Vietnam, Little, Brown and Company, Boston, 1970, pp 21-22.

9. Bourne, P. The Psychology and Physiology of Stress, Academic Press, New York, 1969, pp xiv, 221-222.

10. Ibid, $p$ xiv.

11. Ibid, $p \times v$.

12. Ibid, $p \times v i$

13. Ginzberg, E., Herma, J.L. and Ginsberg, S.W., Psychiatry and Military Manpower Policy, King's Crown Press, New York, 1953, $p 1$.

14. Bourne, 1969, op cit, pp xvi-xvii.

15. Ibid, $p$ xviii.

16. Ingraham, L.H. and Manning. F.J. Psychiatric Battle Casualties: The Missing Column in a War Without Replacements", Military Review, August 1980, p 22.

17. Bourne, 1969 , op cit, pp xviii-xix

18. Ibid, $p \times x$

19. Ibid, $p$ xxii.

20. Kormos, H.R., "The Nature of Combat Stress" in Figley, C.R. (ed), Stress Disorders Among Vietnam Veterans, Brumer/Mazel, New York, 1978. pp 16-17.

21. Ibid, $p 21$.

22. Ingraham and Manning, op cit, p 22.

23. Kellett, A., Combat Motivation, Kluwer Publishing, Boston. 1982, p 276.

24. Ingraham and Manning, op cit, $p 22$.

25. Bourne, 1969, op cit, $p x x$

26. Kormos, op cit, pp 8, 15.

27. Ingraham and Manning, op cit, p 23.

28. Belcher, M.F., "Fear in Combat", Marine Corps Gazette, September 1980 , p 50

29. Strange, R.E., "Effects of Combat Stress on Hospital Ship Psychiatric Evacuees", in Bourne. op cit, 1969. pp 79-80.

30. Cited in Ingraham and Manning, op cit, p 23.

31. Strange, op cit, $p 79$.

32. Ingraham and Manning. op cit, p 23.

33. Langtry, J.D., "We must train junior leaders for the brutal reality of war", Pacific Defence Reporter, October 1982, p 42.

34. Bourne, 1969, op cit, p 233.

35. Ibid, pp 107-109.

36. Ibid, $p$ xxviii.

37. Ibid, p 236.

38. Ibid. $\mathrm{p} 114$.

39. Tischler, G.L., "Patterns of Psychiatric Attrition and of Behaviour in a Combat Zone", in Bourne, op cit, 1969, p 20.

40. Ibid, $p 21$

41. Ibid, p 22

42. De Fazio. V.J., "Dynamic Perspectives on the Nature and Effects of Combat Stress., in Figley, op cit, $p 29$

43. Zais and Taylor, op cit, p 203

44. Ingraham and Manning, op cit, p 27 
45. Tischler, op cit, $\mathrm{p} 227$.

46. Ingraham and Manning, op cit, p 26

47. Lifton, R.J., "Advocacy and Corruption in the Healing Profession" in Figley, op cit, $\mathrm{p} 223$

48. Kormos, op cit, $p 11$.

49. Richardson, F.M., Fighting Spirit, Leo Cooper, London, 1978, p 107.

50. Tischler, op cit, p 23.

51. Ginzberg, op cit, p 36

52. Zais and Taylor, op cit, p 206.

53. Smith, op cit, p 12.

54. Zais and Taylor, op cit, p 206.

55. Smith, op cit, $p 12$.

56. Chermol, B., "Stress Management for Aviators", U.S. Army Aviation Digest, January 1981, p 16

57. Zais and Taylor, op cit, p 205.

58. Ibid, p 206

59. Richardson, op cit, $p 76$

60. Ibid, p 112

61. Langtry, $O p$ cit, p 45

62. Thompson, H.L., "Sleep loss and its Effect in Combat", Military Review. September, 1983, p 19.

63. Forster, M.J.D.. "The nature of Fear and Stress in General War", The Jounral of the Royal Artillery, September 1983, p 105.64. Langtry, op cit, p 45 .

lbid, 045

Ingraham and Manning, op cit, $\mathrm{p} 24$.

67. Richardson, op cit, p 96.

68. Ibid, $p 103$.

69. Bourne, op cit, 1969, p 11

70. Sarkesian, S.C., Combat Effectiveness, Sage Publications, Beverley hills, 1980, p 204
71. Zais and Taylor, op cit, 0204

72. Wesbrook, S.D., "The Potential for Military Disintegration" in Sarkesian, op cit, p 257

73. Ibid, o 259 .

74. Forster, op cit, p 107.

75. Ibid, p 106.

76. Zais and Taylor, op cit, op 204

77. Belcher, op cit, p 50

78. Forster, op cit, $\mathrm{p} 107$.

79. Kellett, op cit, $\mathrm{p} 91$

80. Richardson, op cit, p 124.

81. Ibid, pp $67-68$.

82. Cited in Barlotta, S.J., "Basic Training: The Verge of Destruction", Armed Forces, June 1981, p 24.

83. Ibid, p 25 .

84. Forster, op cit, 108.

85. Barlotta, op cit, p 25.

86. Ibid, p 28.

87. Langtry, $O p$ cit, $p 43$

88. Rolbant, S., The Israeli Soldier, Thomas Yoselott, Cranbury, New Jersey, 1970. p 196.

89. Ibid, pp 197-198

90. Cited in Richardson, op cit, $p 137$

91. Moran, The Anatomy of Courage, Constable, London, 1966, pp 162, 166.

92. Figley, op cit, pp xxi-xxii.

93. Smith, op cit, $p 16$.

94. Zais and Taylor, op cit, pp 208-210.

95. Gabriel, R.. "Stress in Battle: Coping on the Spot", Army. December 1982, pp 36-42.

96. Zais and Taylor, op cit, p 208. 